Bohdan Boichuk's Childhood Reveries: A Migrant's Nostalgia, or, Documenting Pain in Poetry

Author(s): Maria G. Rewakowicz

Source: Kyiv-Mohyla Humanities Journal 5 (2018): 133-142

Published by: National University of Kyiv-Mohyla Academy

http://kmhj.ukma.edu.ua/ 


\title{
Bohdan Boichuk's Childhood Reveries: A Migrant's Nostalgia, or, Documenting Pain in Poetry
}

\author{
Maria G. Rewakowicz \\ Rutgers University - New Brunswick \\ Department of German, Russian, and East European Languages and Literatures
}

\begin{abstract}
This paper examines Bohdan Boichuk's poetry by looking into the role his childhood memories played in forming his poetic imagination. Displaced by World War II, the poet displays a unique capacity to transcend his traumatic experiences by engaging in creative writing. Eyewitnessing war atrocities perpetrated by the Nazis does not destroy his belief in the healing power of poetry; on the contrary, it makes him appreciate poetry as the only existentially worthy enterprise. Invoking Gaston Bachelard's classic work The Poetics of Reveries: Childhood, Language, and the Cosmos, I argue that Boichuk's vivid childhood memories, however painful they might be, helped him poetically recreate and reimagine fateful moments of his migrant life.
\end{abstract}

Key Words: war and poetry, childhood memories, migrant displacement, Bohdan Boichuk, Gaston Bachelard.

\section{(7)}

In his book The Poetics of Reverie: Childhood, Language, and the Cosmos, the French philosopher Gaston Bachelard (1884-1963) underscores the importance of childhood memories in forming a poetic imagination. "An excess of childhood is the germ of a poem," he insists, explaining how the happiness of the child's dreaming in solitude precedes the happiness of the poet engendering an image. ${ }^{1}$ By invoking that inner child in ourselves, we can poetically recreate or reimagine fateful moments in our lives. Bachelard further states: "To reach the memories of our solitudes, we idealize the worlds in which we were solitary children" ${ }^{2}$ and then concludes: "The child sees everything big and beautiful. The reverie toward childhood returns us to the beauty of the first images." ${ }^{3}$ However, as I will argue below, for some poets, the rekindling of childhood memories often entails a reverie of flight, trauma, and pain, especially if those memories are inextricably linked to personal loss and, moreover, are rooted in war and displacement. In other words, somewhat undermining Bachelard's approach,

\footnotetext{
1 Gaston Bachelard, The Poetics of Reverie: Childhood, Language, and the Cosmos (Boston: Beacon Press, 1971), 100.

2 Bachelard, The Poetics of Reverie, 101.

3 Bachelard, The Poetics of Reverie, 102-03.
} 
I contend that childhood traumatic memories can be as inspiring and productive when it comes to engendering poetic images as memories stemming from happy experiences.

Even those who are only superficially acquainted with the poetry of Bohdan Boichuk (1927-2017) can easily discern how important his childhood memories had become for him throughout his long poetic journey. But Boichuk's inner child, in contrast to Bachelard's ruminations about childhood reveries, remembers everything through the prism of pain and suffering. It is no wonder, then, that the poet named his debut collection Chas boliu (The Time of Pain, 1957) — even his coming into this world occurred through pain, and he eagerly thanks his mother for giving him life when, heartbroken, he faces her death at the age of thirteen:

\author{
For everything: \\ for a ripped yell \\ on a bed of birth, \\ for pain \\ knotting your insides, \\ for moans, \\ and for the baby \\ between your knees \\ bursting with a loud cry. \\ For everything. ${ }^{4}$
}

(Zavse: / za peredertyi kryk/na lozhi rodzhennia / ismerty, / za bil, / shcho omotav utrobu, / za stohin, / skryvleni usta, / iza dytia v tvoikh kolinakh, / shcho bryznulo plachem. / Za vse. ${ }^{5}$ )

Later, in his long poem Podorozh z uchytelem (Journey with a Teacher, 1976), Boichuk also invokes the death of his mother but does so in a more restrained way:
A bell struck at the collapsed hut.
And I froze in its threshold - giving my departing mom
a withered lilac branch and a clod of clay -
nothing else. ${ }^{6}$

Bohdan Boichuk, Memories of Love: Selected Poems of Bohdan Boychuk, trans. David Ignatow and Mark Rudman (Riverdale-on-Hudson, NY: The Sheep Meadow Press, 1989), 75. Translated by David Ignatow.

5 Bohdan Boichuk, Virshi vybrani i peredostanni [Poems, Selected and Next to the Last] (New York: Suchasnist, 1983), 13-14. With one exception indicated below, all early poems quoted here are versions included in this 1983 edition.

$6 \quad$ All translations are my own unless indicated otherwise. 
(Udaryv dzvin v obvalenu khatynu. / A ya v porozi vris - i materiv dorohu / pryvialyi kushch i hrudku hlyny —/bilsh nichoho.7)

By handling the memory of his mother's passing in such a minimalistic and metonymic manner ("a withered lilac branch and a clod of clay" stand for his depiction of a funeral), the poet underscores the abyss of pain experienced by him as a 13-year-old boy. Perhaps that is why he returns to his childhood memories reluctantly, although at the same time he feels compelled to reminisce about what he had witnessed, almost as if it was his duty to poetically document what had been seen and internalized:

I dragged through the stubble of life my childhood out of wormwood and mint, erasing candor from my face to survive and to outwait.

My path cut through the hills from my home to the school in town, wherever my steps followed white-bark birches would grow.

(Ya potiahnuv sternynoiu zhyttia / svoie dytynstvo z polynu i miaty, / vidvertist vytyraiuchy z lytsia, / shchob perezhyty i perezhdaty. // Moia doroha rizalas $v$ horby / vid khaty do miskoi shkoly, - I de padaly moi slidy, berezy ryrostaly bilokori. ${ }^{8}$ )

In Boichuk's poetry there is no idealization of childhood memories; it is just all about remembering and experiencing.

In his brief "Introduction" to the translated volume Memories of Love: The Selected Poems of Bohdan Boychuk (1989), Mark Rudman could not have captured the Ukrainian émigré poet's biographical details more succinctly:

Bohdan Boychuk was born in 1927 in a small peasant village in the Western Ukraine. In an autobiographical sketch he describes his childhood as "rich in poverty, simplicity, and the beauty of nature." But this pastoral situation, that "delicate balance of survival" was tilted by the events of World War II. Captured by the Germans, he spent the last months of the war doing hard labor. The next four years he spent in a Displaced Persons camp in Aschaffenburg, West

7 Boichuk, Virshivybrani i peredostanni, 75 .

8 Boichuk, Virshi vybrani i peredostanni, 78. 
Germany, where he completed his high school education. In 1949 he came to America and enrolled in the City College of New York. ${ }^{9}$

And yet, this short paragraph sufficiently sketches a migrant's solitary journey from his place of birth and childhood to a new place where he matured as a poet. While the poet's adopted homeland facilitates for him a free artistic development and he embraces his displacement without grudges, his memories of horrendous World War II atrocities continue living in his mind and press to be artistically reimagined. ${ }^{10}$

Arguably, the most striking picture that his inner child poetically testifies to is the tragedy he witnessed as a schoolboy in the town of Buchach in Western Ukraine, absorbing the shock of the Nazis killing a Jewish woman on the street:

suddenly close to the Sobiesky Well

on the Railroad Street I noticed

a killed woman with a Jewish profile, her body stuck to the asphalt with her arms spread out to the world, and next to her lay her crying handbag, shedding beads, pins and the warmth of small accessories of female essence.

(azh pid krynytseiu Sobieskoho naraz / azh na Koliiovii vulytsi pomityv, // yak do asfaltu tilom pryrosla / z hebreiskym profilom zabyta zhinka, / rozkynuvshy po sviti ramena, / a zboku plakala yii torbynka: // koraliamy, shpylkamy i teplom / malykh prykras zhinochoi pryrody. ${ }^{11}$ )

The image of the Jewish woman murdered by the Nazi Germans left such an imprint on young Boichuk that he returned to it again in his cycle of poems titled Liubov u triokh chasakh (Three Dimensional Love, 1974-1976):

After the night Action on the Jews, as the Gestapo chased over the empty streets, hunting and shooting, I was headed down Railroad Street to the Commercial School. Near Sobiesky Well I saw

9 Mark Rudman, "Introduction," in Memories of Love: Selected Poems of Bohdan Boychuk, trans. David Ignatow and Mark Rudman (Riverdale-on-Hudson, NY: The Sheep Meadow Press, 1989), 7 .

10 I elaborate on this in greater detail in my monograph on the poetry of the New York Group. See Literature, Exile, Alterity: The New York Group of Ukrainian Poets (Boston: Academic Studies Press, 2014), 46-48. 
a woman fallen in the middle of the street with her arms spread. Her head had been splintered by a bullet. Her hair was dark brown. At her side lay an opened handbag, spilling pins, beads, combs... ${ }^{12}$

Clearly, the poet provides more details in this prose rendition of the tragic incident. Here we learn, for example, that the woman was shot in the head, and we are also provided with the context for this brutal killing - the night action on the Jews; therefore, although there is no mention this time that the woman is Jewish, it is easy to infer from the preceding statement that this is in fact the case.

Three Dimensional Love is considerably more than just another Holocaust poem. The tripartite structure of the work, consisting of the songlike quatrain, free verse, and prose poem, presents different variations on the theme of love, from the ethereal beauty and possibilities of carnal sensuality, through mundane, if not brutal, realities of everyday existence, fleeting to the painful, yet hopeful, memories of the past. In the end, the most revealing and captivating part of the poem is the story told in the last prose segment. It relies on the childhood memories of a first teenage love amid the unfolding Nazi atrocities. The girl with whom the lyrical hero falls in love and spends a few precious moments among the town's ruins, or swimming in the nearby river, eventually disappears (presumably killed), leaving the young lover forever longing for her and searching for her his whole life, while feeling guilty for being the one who survived:

A final silence collected in the glassy eyes of the dead. I was the only one who kept on walking over the earth of her absence, with the presence of the shadows of the executed, with the holes of crematoria. Why did I have to endure it? In the final account, the monastery on Raven Hill was a betrayal. The woman near Sobiesky Well — a betrayal. The bodies over the planks of Buchenwald betrayal. My witnessing was also a betrayal. I'm alive. ${ }^{13}$ closer to this original. "Pislia nichnoi aktsii na zhydiv, koly gestapo hanialo porozhnimy kvartalamy, dolovliuiuchy i dostriliuiuchy, ya ishov unyz Koliiovoiu vulytseiu do torhovelnoi shkoly, yaka stoiala naproty ratushi po druhomu botsi Strypy i odnym plechem pidtrymuvala horbok iz starym kladovyshchem. Bilia krynytsi Sobieskoho ya pobachyv zhinku, yaka lezhala posered vulytsi, rozkynuvshy ruky. Yii holova bula rozirvana postrilom, a z chashky tiahnulasia zastyhla krov i klapti lypkoho volossia. Zboku lezhala vidkryta torbynka, z yakoi sypalys shpylky, korali, hrebinets..." Boichuk, Virshi vybrani i peredostanni, 161.

13 Boichuk, Memories of Love, 47. "Ostannia tysha osidala v sklysti ochi mertvykh. Tilky ya odyn khodyv po sviti z vidsutnistiu svoiei divchyny, z prysutnistiu tinei postrilianykh, z yamamy krematorii. Chomu ya mav vse te nesty i znosyty? Vostanniomu rakhunku, manastyr na Krukovii hori-tse zrada. Zhinka bilia krynytsi Sobieskoho_zrada; tila na doshkakh 
Perhaps Rudman was right to conclude in his introduction that Boichuk's "search for the girl could stand as a metaphor for all of his work." ${ }^{14}$ I think, however, that it is more fitting to say that he was also in search of that inner child lost somewhere on his life journey - the child he was too eager to reclaim.

The theme of love and death, so consistently employed by Boichuk throughout his literary career, reappears again in his long poem Kliasa bez visty (The Perished Class, 2014). This is yet another retelling of the love story we first encountered in Three Dimensional Love. The poet actually incorporates its prose segments as mottos in this new poetic rendition of the tragic teenage love between the poor Ukrainian boy and the Jewish girl Yana. In The Perished Class, Boichuk reimagines returning to his elementary school in Monastyryska as an elderly man who takes a seat at a classroom desk just as he used to as a child, but he cannot fathom why all his school friends are absent. The lyrical hero engages in a long conversation with his teacher Chornovus, who is still there (no doubt Boichuk intertextually alludes here to his long poem Journey with a Teacher), and at last understands that all his classmates are already dead. He also learns that his Jewish girlfriend was killed by the Gestapo weeks before he met her again in Buchach. In other words, the poet finally reveals that his love story, so beautifully and touchingly related in Three Dimensional Love, was in fact his childhood reverie, or the past that was dreamt "at the frontier between history and legend," as Bachelard succinctly put it. ${ }^{15}$ It seems that only by spelling out the truth could Boichuk achieve some sense of closure:

The old man looked at the teacher,

who was still sitting on the window sill and listening.

- Teacher, to this very day I don't know what happened to Yana.

I don't know where to look for her.

- Too late to look, — said Black-whiskers, approaching the "cathedral."

- How then can I live without hope?

- Hope is the realm of the living.

I cannot help you with that.

- Teacher, take one more look at the Register. Maybe there's something about her in there.

Black-whiskers carefully examined the book.

- Yes. There is. It says here that Yana,

her brother and her parents, were shot by the Germans

Bukhenvaldu — zrada. Moie svidchennia pro nykh — tezh zrada. Ya zhyvu," Boichuk, Virshi vybrani i peredostanni, 171.

14 Rudman, "Introduction," 14.

15 Bachelard, The Poetics of Reverie, 101. 
in Monastyryska in the spring of 1943.

- Teacher, teacher, read it again.

I don't understand.

- What is there to understand?

Yana was shot a few weeks before you met her in Buchach.

He packed his books and left.16

As the teacher leaves the classroom, the poet seemingly at last leaves the painful memory of his first love. What ensues for the poor boy from Monastyryska is the postwar life of a migrant, full of expectations for the betterment of his lot, yet always implicitly nostalgic about his home that never was.

Exilic displacement is not often thematized by Boichuk. He clearly avoids the motifs of uprootedness and homelessness in his poetry, but the idea of home and its meaning (be it his personal sphere or his relationship to his lost homeland) undoubtedly permeate his poetry. The poet often questions its validity or saliency (and taking into account his life experience, it is quite understandable), but behind such qualms one can easily recognize a migrant's nostalgia:

There was an essence somewhere, only puzzles are left,

home stood somewhere, but how to find it?

My path

suddenly slipped

from underneath my feet,

dissipated like dust

into infinity.

I walked

and sank up to my knees

16 Bohdan Boichuk, Kliasa bez visty: Poema v prozi (Lviv: Piramida, 2014), 82-83. Translated by the author and Roman Boychuk. "Staryi cholovik hlianuv na Chornovusa, / yakyi vse shche sydiv na podvikonni i slukhav. /_Vchyteliu, ya dosi ne znaiu, shcho z neiu stalosia. / Ine znaiu, de za neiu shukaty. /_Zapizno shukaty, —skazav Chornovus, / pidkhodiachy do 'katedry,' de sydiv staryi cholovik. /_A yak todi zhyty bez nadii? / — Nadiia — tse oznaka zhyvykh, i ya ne mozhu tobi zaradyty. / - Vchyteliu, podyvitsia shche u knyhu reiestriv. / Mozhe, shchos poiavylosia za toi chas. / Chornovus uvazhno pereviryv knyhu. /_Tak. Ye. Tut skazano, shcho Yanu, Yii brata i batkiv / rozstrilialy nimtsi na okopysku v Monastyryskakh, /vesnoiu, 1943-ho roku. /_Vchyteliu, vchyteliu, prochytaite shche raz. Ya nichoho ne rozumiiu. /_Nema shcho rozumity. Yanu rozstrilialy / kilka tyzhniv pered tym, / yak ty zustrivsia z neiu v Buchachi, _ / skazav Chornovus, spakuvav svoi papery / i vyishov," Boichuk, Kliasa bez visty, 43. 
into darkness.

On the edge of light years

daylight appeared sometimes,

and from time to time the star

was falling into someone's

hands.

Yes:

home stood somewhere, and, perhaps, did not;

the goal was somewhere,

and, perhaps, was not.

I went somewhere

and knew:

my path leads nowhere;

I went and knew:

my steps are life.

(Des sut bula, / ostalysia odhadky, / des dim stoiav, / ta yak yoho znaity? // Mii shliakh / nezhdano vykhoznuv / z-pid nih; / piskom rozlyvsia /v bezkonechnist. //Ya ishov / ipo kolina hruz /v temnoti. / Na hrani svitlianykh rokiv / yavliavsia chasom den, / i chas vid chasu zirka / padala komus / v doloni. // Tak: / des dim stoiav, / a, mozhe, ne stoiav; / bula des tsil, / a, mozhe, ne bulo. / Ya ishov kudys / i znav: / mii shliakh—nikudy; / ya ishov i znav: / mii khid—zhyttia. ${ }^{17}$ )

In the end there is simply acceptance and reconciliation with one's fate, as well as belief that people alone define their own meaning in life. But an implicit longing for the poet's native land is also there, even if expressed universally and abstractly:

and I want to touch your wounds with my lips

and squeeze black longing out of my heart

onto your hands,

and afterwards to dissolve forever

in the womb of your black soil

and become your body's grass,

Oh, the country of black life.

(ta ya ustamy khochu dotorknuty ran, / i chornu tuhu vydushyty z sertsia / na tvoi spechaleni doloni, / a tak naviky rozchynytysia / u 
loni chornozemu / i prorosty travoiu tvoho tila, // Kraino chornoho zhyttia. ${ }^{18}$ )

Gaston Bachelard cherishes childhood reveries for their ability to connect to a "cosmic memory which does not need the precisions of the social memory" 19 and further states: "In our reverie which imagines while remembering, our past takes on substance again. Over and above the picturesque, the bonds between the world and the human soul are strong. Then there lives within us not a memory of history but a memory of the cosmos." 20 By invoking the painful reveries of childhood, Boichuk not only gave them poetic substance but also laid open his longing to understand the metaphysics of human cruelty through his attempts to reconcile the beauty of the world with the horrors of war. In some ways he seems to be implicitly arguing with Theodor Adorno and his famed statement that "there can be no poetry after Auschwitz." Boichuk entertains the opposite idea. Surviving as a person displaced by war, he appreciates poetry as the only existentially worthy enterprise, no matter how painful:

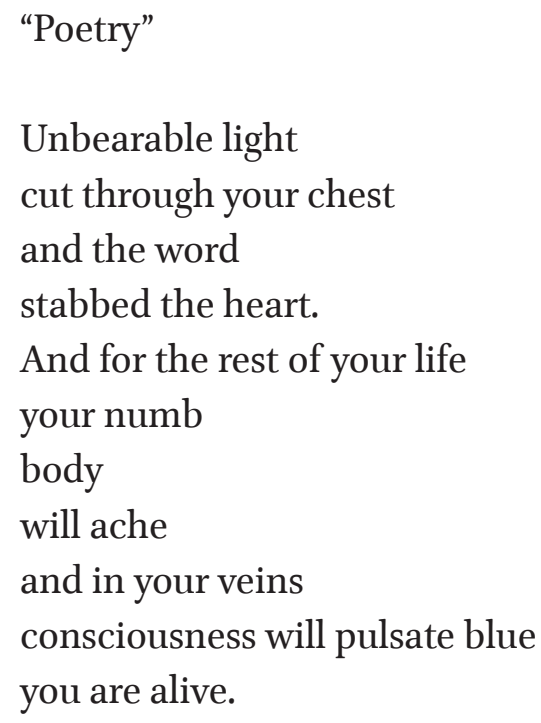

("Poeziia" // Nesterpne svitlo / peretialo hrudy, / iv sertse vrizalosia / slovo.//Ido kintsia tvoho / bolityme/zaterple/tilo, / avzhylakh synio / pulsuvatyme svidomist: / ty zhyvesh. ${ }^{21}$ )

Poetry has the power to convey pain and to heal at the same time. Boichuk could not agree more with Bachelard's conviction that "poetry is a synthesizing force for human existence!" 22 It is only through that force that one can truly feel alive.

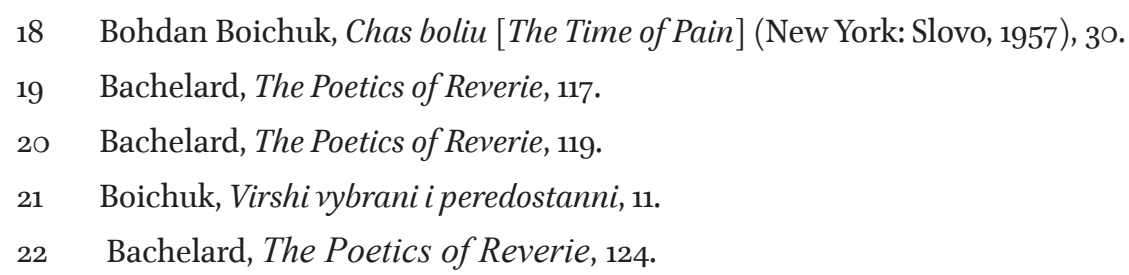




\section{Bibliography}

Bachelard, Gaston. The Poetics of Reverie: Childhood, Language, and the Cosmos. Translated by Daniel Russell. Boston: Beacon Press, 1971.

Boichuk, Bohdan. Chas boliu [The Time of Pain]. New York: Slovo, 1957.

Boichuk, Bohdan. Kliasa bez visty: Poemav prozi. The Perished Class: Poem in Prose. Klasa bez wieści: Poemat proza. Translated by the author and Roman Boychuk. Przekład Tadeusz Karabowicz. Lviv: Piramida, 2014.

Boichuk, Bohdan. Memories of Love: The Selected Poems of Bohdan Boychuk. Translated by David Ignatow and Mark Rudman. Riverdale-on-Hudson, NY: Sheep Meadow Press, 1989 .

Boichuk, Bohdan. Podorozh z uchytelem: poema [Journey with a Teacher: A Poem]. New York: V-vo Niu-Yorkskoi hrupy, 1976.

Boichuk, Bohdan. Virshi vybrani i peredostanni [Poems, Selected and Next to the Last]. New York: Suchasnist', 1983.

Rewakowicz, Maria G. Literature, Exile, Alterity: The New York Group of Ukrainian Poets. Boston: Academic Studies Press, 2014.

Rudman, Mark. "Introduction." In Memories of Love: Selected Poems of Bohdan Boychuk. Translated by David Ignatow and Mark Rudman, 7-14. Riverdale-on-Hudson, NY: Sheep Meadow Press, 1989.

Maria G. Rewakowicz, PhD (University of Toronto) teaches Ukrainian literature at Rutgers University - New Brunswick and is also affiliated with the Department of Slavic Languages and Literatures at the University of Washington. She is the author of Literature, Exile, Alterity: The New York Group of Ukrainian Poets (2014) and co-editor of Contemporary Ukraine on the Cultural Map of Europe (2009). She also authored a book of essays, Persona non grata (2012), and compiled two anthologies of the New York Group poetry, all three published in Ukraine. Her most recent publication is Ukraine's Quest for Identity: Embracing Cultural Hybridity in Literary Imagination, 1991-2011 (2018). 